\title{
Critical role for thyroid hormone receptor $\beta 2$ in the regulation of paraventricular thyrotropin-releasing hormone neurons
}

\author{
E. Dale Abel, ${ }^{1}$ Rexford S. Ahima, ${ }^{2}$ Mary-Ellen Boers, ${ }^{3}$ Joel K. Elmquist, ${ }^{3}$ \\ and Fredric E. Wondisford ${ }^{4}$
}

${ }^{1}$ Division of Endocrinology, Metabolism and Diabetes and Program in Human Molecular Biology and Genetics,
University of Utah, Salt Lake City, Utah, USA
2Division of Endocrinology, Diabetes and Metabolism, University of Pennsylvania School of Medicine,
Philadelphia, Pennsylvania, USA
${ }^{3}$ Division of Endocrinology and Metabolism, Beth Israel Deaconess Medical Center and Harvard Medical School,
Boston, Massachusetts, USA
${ }^{4}$ Section of Endocrinology and Metabolism, Pritzker School of Medicine, The University of Chicago, Chicago, Illinois, USA

Address correspondence to: E. Dale Abel, Division of Endocrinology, Metabolism and Diabetes and Program in Human Molecular Biology and Genetics, University of Utah School of Medicine, 15 North 2030 East, Building 533, Room 3410 B, Salt Lake City, Utah 84112, USA. Phone: (801) 585-0727; Fax: (801) 585-0701; E-mail: dale.abel@hmbg.utah.edu.

Address reprint requests to: Frederic E. Wondisford, Section of Endocrinology and Metabolism, Pritzker School of Medicine, The University of Chicago, 5841 S. Maryland Avenue MC 1027, Chicago, Illinois 60637, USA.

Received for publication July 26, 2000, and accepted in revised form March 13, 2001.

Thyroid hormone thyroxine $\left(\mathrm{T}_{4}\right)$ and tri-iodothyronine $\left(\mathrm{T}_{3}\right)$ production is regulated by feedback inhibition of thyrotropin (TSH) and thyrotropin-releasing hormone (TRH) synthesis in the pituitary and hypothalamus when $\mathrm{T}_{3}$ binds to thyroid hormone receptors (TRs) interacting with the promoters of the genes for the TSH subunit and TRH. All of the TR isoforms likely participate in the negative regulation of TSH production in vivo, but the identity of the specific TR isoforms that negatively regulate TRH production are less clear. To clarify the role of the TR- $\beta 2$ isoform in the regulation of TRH gene expression in the hypothalamic paraventricular nucleus, we examined preprothyrotropin-releasing hormone (prepro-TRH) expression in mice lacking the TR- $\beta 2$ isoform under basal conditions, after the induction of hypothyroidism with propylthiouracil, and in response to $T_{3}$ administration. Prepro-TRH expression was increased in hypothyroid wild-type mice and markedly suppressed after $\mathrm{T}_{3}$ administration. In contrast, basal TRH expression was increased in TR- $\beta 2$-null mice to levels seen in hypothyroid wild-type mice and did not change significantly in response to induction of hypothyroidism or $\mathrm{T}_{3}$ treatment. However, the suppression of TRH mRNA expression in response to leptin reduction during fasting was preserved in TR- $\beta 2$-null mice. Thus TR- $\beta 2$ is the key TR isoform responsible for $\mathrm{T}_{3}$-mediated negative-feedback regulation by hypophysiotropic TRH neurons.

J. Clin. Invest. 107:1017-1023 (2001).

\section{Introduction}

Thyroid hormone concentrations in vivo are maintained in a narrow range by the ability of thyroid hormone to limit its own production by feedback inhibition of the synthesis of thyrotropin (TSH) by pituitary thyrotrophs (1). TSH synthesis and bioactivity is also regulated by thyrotropin-releasing hormone (TRH) originating from hypothalamic paraventricular TRH neurons $(2,3)$. Thyroid hormone mediates the negative regulation of the TSH subunit and TRH genes by binding to thyroid hormone receptors (TRs) that interact with thyroid hormone-responsive elements on the promoters of these genes (4-6). Three tri-iodothyronine $\left(\mathrm{T}_{3}\right)$ binding isoforms of the thyroid hormone exist: TR- $\alpha 1$, TR- $\beta 1$, and TR- $\beta 2$ (7). These isoforms are all expressed within the thyrotroph (8) and the TRH neurons of the paraventricular hypothalamus (9). However, TR- $\beta 2$ is the most abundant isoform in the thy- rotroph (10) and potentially in the TRH neurons of the paraventricular hypothalamus (9). Indeed, the restricted expression of TR- $\beta 2$ (thyrotroph, TRH neurons of the paraventricular hypothalamus, developing ear, and developing retina) contrasts with the ubiquitous expression of TR- $\alpha 1$ and TR- $\beta 1$ isoforms (7). Thus, the expression pattern of TR- $\beta 2$ suggests that this isoform may be the important mediator of negative regulation of TSH and TRH production by $\mathrm{T}_{3}$.

Transgenic and knockout animals have shed important insight into the relative roles of TR isoforms in the regulation by thyroid hormone of the hypothalamicpituitary-thyroid (HPT) axis. Mice with targeted ablation of the TR- $\alpha$ locus (11) or the TR- $\alpha 1$ gene (12) develop minor abnormalities in thyroxine $\left(\mathrm{T}_{4}\right)$ and TSH concentrations. Mice that lack both TR- $\beta$ isoforms (TR$\beta$ null) develop elevated concentrations of $\mathrm{T}_{4}$ and TSH and exhibit partial suppression of TSH production after 
the administration of exogenous $T_{3}(13,14)$. The partial suppression of TSH production in this model suggests that the residual TR- $\alpha 1$ is capable, in part, of mediating the inhibition of TSH production by $\mathrm{T}_{3}$. We have shown recently that the hormonal abnormalities observed in TR- $\beta$-null mice are largely recapitulated in mice with selective ablation of TR- $\beta 2$ (15), suggesting that TR- $\beta 2$ is the important mediator of $\mathrm{T}_{3}$-mediated negative regulation of the HPT axis. It is of interest that mice that lack all TR isoforms develop dramatic increases in thyroid hormone concentrations, indicating that normal expression of TR- $\alpha$ and TR- $\beta$ are ultimately required for normal regulation of the HPT axis $(16,17)$. It is not clear, however, if defective negative regulation is occurring equally at the level of the thyrotroph or the TRH neuron. An important role for hypothalamic TRH production in mediating the increased thyroid hormone concentrations associated with resistance to thyroid hormone was demonstrated by our laboratory in transgenic mice with pituitary-selective expression of a mutant TR (18). These animals developed elevated levels of TSH with relatively normal concentrations of $\mathrm{T}_{4}$, which only became significantly elevated after TRH administration. In contrast, expression of this mutant in the pituitaries of TR- $\beta$-null mice recapitulated the severe thyroid hormone abnormalities observed in compound knock-out mice lacking TR- $\alpha$ and TR- $\beta$ isoforms (19). These observations raise the possibility that TR- $\alpha$ and TR- $\beta$ isoforms serve differential roles in the regulation of TSH and TRH gene expression in the thyrotroph and the TRH neurons of the paraventricular nucleus (PVN) respectively, and suggest that TR- $\beta$ isoforms might be the important mediators of negative regulation in the hypothalamus.

To test the hypothesis that the TR- $\beta 2$ isoform mediates the negative feedback regulation of TRH expression in vivo, we have analyzed the effect of targeted disruption of TR- $\beta 2$ expression on the response of PVN TRH mRNA expression to hypothyroidism and $T_{3}$ administration in mice. Furthermore, we determined whether TR- $\beta 2$ expression is required for leptin-mediated suppression of TRH mRNA expression in the PVN during fasting (20). We found complete absence of thyroid hormone responsiveness in the TRH neurons of TR- $\beta 2$-null mice, but preserved responsiveness to fasting and leptin. These data suggest that the TR- $\beta 2$ isoform is the critical mediator of the negative regulation of TRH expression by thyroid hormone in vivo.

\section{Methods}

Animals. TR- $\beta 2$-null mice were generated as described previously (15). Studies were performed on null mice and wild-type age-matched controls of the same strain. All aspects of animal care and experimentation performed in this study were approved by the Institutional Animal Care and Use Committee of the Beth Israel Deaconess Medical Center (Boston, Massachusetts, USA). Animals were maintained on a 12 -hour light/12-hour dark schedule (light on at $6 \mathrm{am}$ ) and fed laboratory chow and water ad libitum. Blood was obtained for total $\mathrm{T}_{4}$ and TSH by cardiac puncture at the time of sacrifice. Experimental hypothyroidism was induced by placing mice on a low-iodine-propylthiouracil diet (low-iodine-PTU diet) (Harlan Teklad Laboratory, Madison, Wisconsin, USA) for 25 days. Hyperthyroidism was induced by daily intraperitoneal injections of $\mathrm{T}_{3}(1 \mu \mathrm{g} / \mathrm{ml})$ in buffered HEPES for 3 weeks at doses of $0.2 \mu \mathrm{g} / 100 \mathrm{~g}$ body weight during the first week, $0.5 \mu \mathrm{g} / 100 \mathrm{~g}$ body weight during the second week, and $1.0 \mu \mathrm{g} / 100 \mathrm{~g}$ body weight during the third week. Additional experiments were performed to determine the responsiveness of TRH neurons to fasting and leptin administration (20). Wild-type and TR$\beta 2$-null mice were divided into three groups. Group 1 was maintained on normal chow. Group 2 fasted for 48 hours and received four "sham" intraperitoneal injections of $0.3 \mathrm{ml} 0.9 \%$ saline every 12 hours (first dose given 12 hours after the beginning of the fast). Group 3 fasted for 48 hours and received four intraperitoneal injections of leptin $(1 \mu \mathrm{g} / \mathrm{g}$ body weight) every 12 hours (first dose given 12 hours after the beginning of the fast). Blood was obtained for $\mathrm{T}_{4}$ assays at base line and after 48 hours of fasting. Mice were sacrificed at 48 hours.

Hormone assays. Total $\mathrm{T}_{4}$ levels were measured in duplicate $10-\mu l$ serum samples by a specific RIA (ImmuChem coated tube- ${ }_{4}{ }^{125}$ I RIA Kit; ICN Pharmaceuticals Inc., Costa Mesa, California, USA). TSH was measured in $25-\mu \mathrm{l}$ serum samples in triplicate determinations by a specific mouse TSH RIA using a mouse $\mathrm{TSH} /$ luteinizing hormone (TSH/LH) reference preparation (AFP51718mp), a mouse TSH anti-serum (AFP98991), and rat TSH antigen for radioiodination (NIDDK-rTSH-I-9). All reagents were obtained from A.F. Parlow (Harbor University of California at Los Angeles Medical Center, Torrance, California, USA). The standard curve was performed in hyperthyroid mouse serum, and the limit of sensitivity was less than $1.2 \mathrm{ng} / \mathrm{ml}$. The interassay and intra-assay variations were less than $6 \%$.

Localization and quantification of preprothyrotropinreleasing hormone $m R N A$ by in situ bybridization histochemistry. Wild-type and TR- $\beta 2$-null mice, three to four per group, were anesthetized with an intraperitoneal injection of sodium pentobarbital $(50 \mathrm{mg} / \mathrm{kg})$. They were perfused transcardially with PBS prepared with di-ethylpyrocarbonate-treated (DEPC-treated) water, followed by $10 \%$ neutral buffered formalin.

\section{Table 1}

Serum $\mathrm{T}_{4}$ and $\mathrm{TSH}$ concentrations

\begin{tabular}{lcccc}
\hline & \multicolumn{2}{c}{$\mathrm{T}_{4}(\mu \mathrm{g} / \mathrm{dl})$} & \multicolumn{2}{c}{ TSH $(\mathrm{ng} / \mathrm{ml})$} \\
Basal & PTU & Basal & PTU \\
WT & $3.56 \pm 0.4^{\mathrm{A}}$ & $<0.5$ & $<1.2^{\mathrm{A}}$ & $167 \pm 40^{\mathrm{B}}$ \\
TR- $\beta 2 \mathrm{KO}$ & $6.21 \pm 0.4$ & $<0.5$ & $6.1 \pm 1.5$ & $14.1 \pm 1.7$
\end{tabular}

For basal samples $n=7$ (WT) and $n=9(\mathrm{KO})$; for PTU-treated samples $n=4$ $(\mathrm{WT})$ and $n=5(\mathrm{KO})$. Data are means \pm SEM. WT, wild-type; KO, knockout. ${ }^{A} P<0.001,{ }^{B} P<0.01$, versus similarly treated $\mathrm{KO}$ mice $(t$ test $)$. 


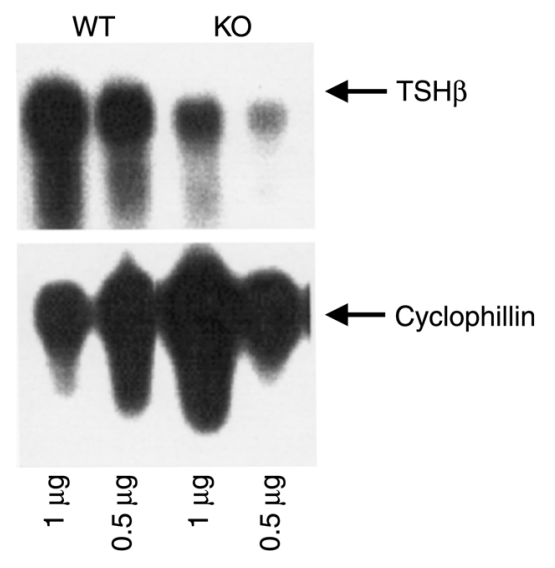

\section{Figure 1}

TSH response to PTU-induced hypothyroidism. Northern blot analysis of total RNA obtained from pooled pituitaries: $n=3$ for wild-type (WT) and TR- $\beta 2$-null (KO), demonstrating TSH $\beta$ mRNA responses in hypothyroid WT and KO mice. Amount of RNA loaded in each lane (in micrograms) is shown.

Brains were removed, immersed in the same fixative overnight, and then cryoprotected in $20 \%$ sucrose in PBS-DEPC at $4{ }^{\circ} \mathrm{C}$. Five series of $20-\mu \mathrm{m}$ coronal sections were cut on a table-top cryotome and mounted on Superfrost Plus glass slides (Fisher Scientific Co., Pittsburgh, Pennsylvania, USA). The protocol for in situ hybridization histochemistry has been described previously (21). Preprothyrotropin-releasing hormone (prepro-TRH) mRNA was localized using a ${ }^{35} \mathrm{~S}$ UTP-labeled complementary RNA probe synthesized from a plasmid containing the cDNA for the mouse prepro-TRH gene (kind gift of Masatomo Mori, Gunma University, Maebashi, Japan). Control sections were hybridized with a sense cRNA probe. The slides were exposed to Kodak Biomax MR film (Eastman Kodak Co., Rochester, New York, USA) for 2 days, after which they were dipped in Kodak NTB2 photographic emulsion, developed after 4 days of exposure, and counterstained with cresyl violet. Brain sections were analyzed with a Nikon E600 microscope equipped with SPOT RT digital camera and software v3.0 (SPOT Diagnostics, Sterling Heights, Michigan, USA). Digitized dark-field photomicrographs of the PVN were saved as Adobe Photoshop 4.0 files (Adobe Systems Inc., San Jose, California, USA). Film autoradiograms of the hypothalamic PVN and thalamic reticular nucleus (RT), corresponding to bregma $-0.58 \mathrm{~mm},-0.82 \mathrm{~mm}$ and $-1.22 \mathrm{~mm}$, respectively (figures 36, 38 and 41 of Franklin and Paxino; ref. 22), from three to four wild-type and three to four transgenic mice, respectively, were selected, coded, and analyzed blindly by computerized laser densitometry (Molecular Dynamics, Sunnyvale, California, USA). Integrated densities of prepro-TRH mRNA in each half of the brain were summed, and mean densities in the PVN and RT were determined in each animal.
Statistical analysis. Differences in hormone concentrations were assessed by the unpaired Student's $t$ test. The level of TRH mRNA expression (assessed by densitometry of film autoradiograms) was compared by ANOVA. Differences between treatment groups as assessed by the Fisher protected least-significant difference (PLSD) test were deemed significant if the $P$ value was less than 0.05 .

\section{Results}

Hormone levels. Table 1 shows serum $\mathrm{T}_{4}$ and TSH concentrations in TR- $\beta 2$-null and control mice under basal conditions and after PTU treatment. As reported previously (15), TR- $\beta 2$-null mice displayed increased basal $\mathrm{T}_{4}$ and TSH concentrations. After PTU treatment, $\mathrm{T}_{4}$ levels decreased below the level of assay detection. TSH concentrations rose in both groups of mice. However, as was demonstrated previously using $\mathrm{I}^{131}$-induced hypothyroidism (15), the rise in TSH was markedly blunted in hypothyroid TR- $\beta 2-$ null mice. We confirmed by Northern blot analysis that the blunted increase in TSH concentration in TR- $\beta 2$-null mice was the result of impaired activation of TSH $\beta$ gene expression (Figure 1). In our earlier study we also demonstrated that administration of $T_{3}$ to TR- $\beta 2$-null mice, resulted in partial suppression of serum $\mathrm{T}_{4}$ concentrations and TSH $\beta$ gene expression (15). Similar results were obtained in this study (data not shown).
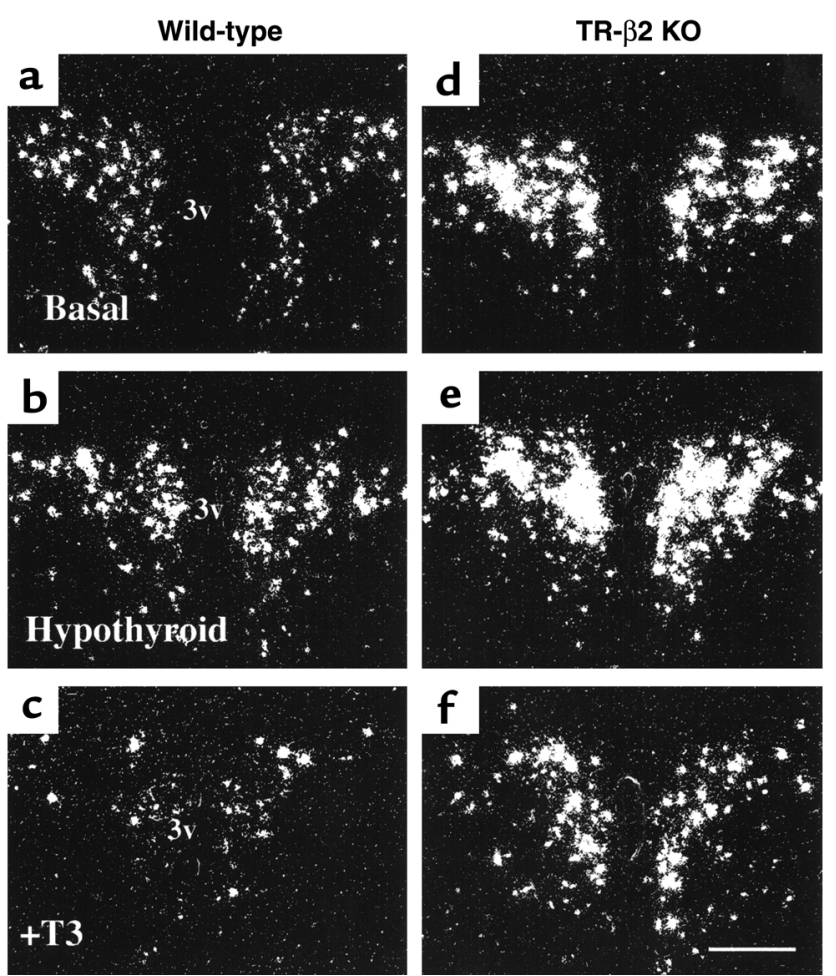

Figure 2

(a-f) Representative dark-field photomicrographs showing preproTRH mRNA in the rostral PVN of WT (a-c) and TR- $\beta 2$-null (KO) mice (d-f). Treatment conditions are as shown: basal (a and $\mathbf{d})$, hypothyroid (b and $\mathbf{e}$ ), and $\mathrm{T}_{3}$-treated (c and $\mathbf{f}$ ). Scale bar, $300 \mu \mathrm{m}$. 

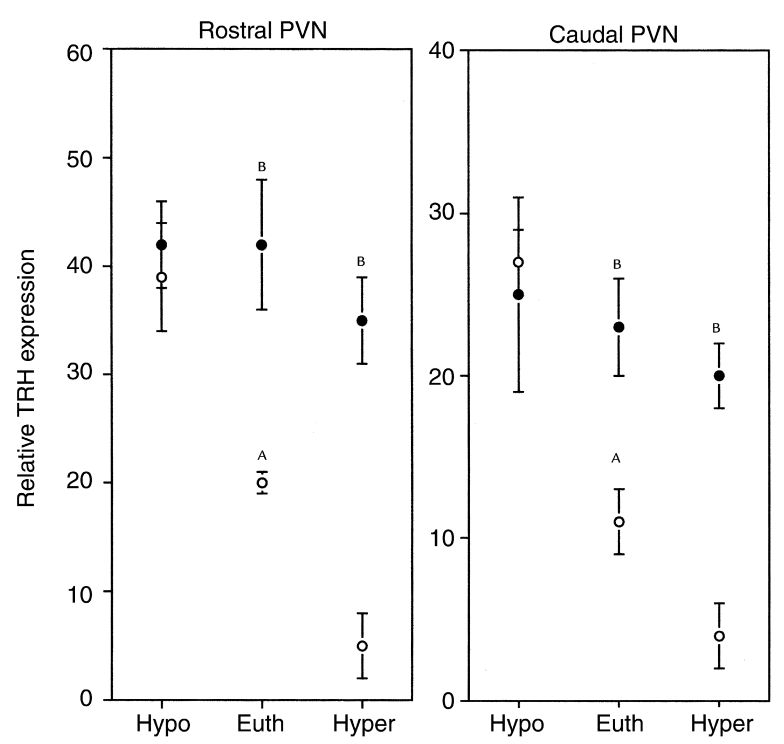

TRH expression. Representative dark-field photomicrographs in rostral and caudal levels in the PVN of TR$\beta 2$-null and wild-type (WT) mice under basal conditions and after treatment with either PTU or $\mathrm{T}_{3}$ are shown in Figures 2 and 3. Densitometric analysis (Figure 4) revealed that basal prepro-TRH expression in rostral and caudal PVN regions were increased twofold $(P<0.05)$ in null versus wild-type mice. Prepro-TRH expression in the rostral and caudal PVN of wild-type mice were increased twofold and 2.5-fold, respectively, above basal after PTU and reduced by $75 \%$ and $65 \%$, respectively, below basal after $\mathrm{T}_{3}$ administration $(P<0.05)$. In contrast, prepro-TRH gene expression in null mice was completely unresponsive to changes in ambient thyroid hormone concentrations.

Effect of fasting and leptin administration. To determine if the lack of TRH responsiveness was selective for $\mathrm{T}_{3}$ mediated pathways; we analyzed thyroid hormone levels and prepro-TRH gene expression in the PVN of wild-type and TR- $\beta 2$-null mice after fasting and leptin administration. As shown in Figure 5a, fasting resulted in suppression of $\mathrm{T}_{4}$ to levels that were below the limit of detection of the $\mathrm{T}_{4}$ assay in wild-type and null mice. In leptin-treated animals the degree of $\mathrm{T}_{4}$ suppression was blunted. However, $\mathrm{T}_{4}$ concentrations in leptin-treated TR- $\beta 2$-null mice remained significantly higher than levels in leptin-treated wild-type mice. Importantly, analysis of TRH expression (Figure 5b and Figure 6) demonstrated a significant reduction in TRH gene expression with fasting, which was reversed after leptin administration. Leptin regulation of TRH expression was observed in wild-type and TR- $\beta 2$-null

\section{Figure 3}

(a-f) Representative dark-field photomicrographs showing preproTRH mRNA in the caudal PVN of WT (a-c) and TR- $\beta 2$-null (KO) mice (d-f). Treatment conditions are as shown: basal (a and $\mathbf{d})$, hypothyroid (b and $\mathbf{e}$ ), and $\mathrm{T}_{3}$-treated (c and $\mathbf{f}$ ). Scale bar, $300 \mu \mathrm{m}$.

\section{Figure 4}

Relative prepro-TRH expression as assessed by laser densitometry in the rostral and caudal PVN of WT (open circles) and TR- $\beta 2-$ null (KO; filled circles) mice. Data shown are mean \pm SEM. Each point represents analysis of anatomically identical sections from three separate animals. ${ }^{A} P<0.05$ versus hypo and hyper WT, respectively, by ANOVA. ${ }^{B} P<0.05$ versus WT in the same treatment group. Hypo, PTU-treated mice; Euth, untreated mice (basal conditions); Hyper, $\mathrm{T}_{3}$-treated mice.

mice. However TRH expression remained higher in TR- $\beta 2$-null mice than wild-type under equivalent treatment conditions.

\section{Discussion}

This study demonstrates, we believe for the first time, that the TR- $\beta 2$ isoform is the key mediator of negative regulation in the $\mathrm{T}_{3}$-responsive neurons of the PVN. We have shown previously that TR- $\beta 1$ and TR- $\alpha$ expression are normal in TR- $\beta 2$ knockout mice (15). Thus, in contrast to the thyrotroph where the remaining isoforms partially mediate negative regulation, in the hypothalamus this is not the case. These data therefore suggest that important differences between the thyrotroph and the PVN exist in terms of the roles of TR isoforms in mediating negative regulation in vivo.

Basal $\mathrm{T}_{4}$ and TSH concentrations are increased in TR- $\beta 2$ knockout mice, consistent with central resistance to thyroid hormone (RTH). Our previous data obtained in mice with pituitary-selective expression of a mutant TR- $\beta$ suggested that increased production of both TSH and TRH at ambient levels of thyroid hor-
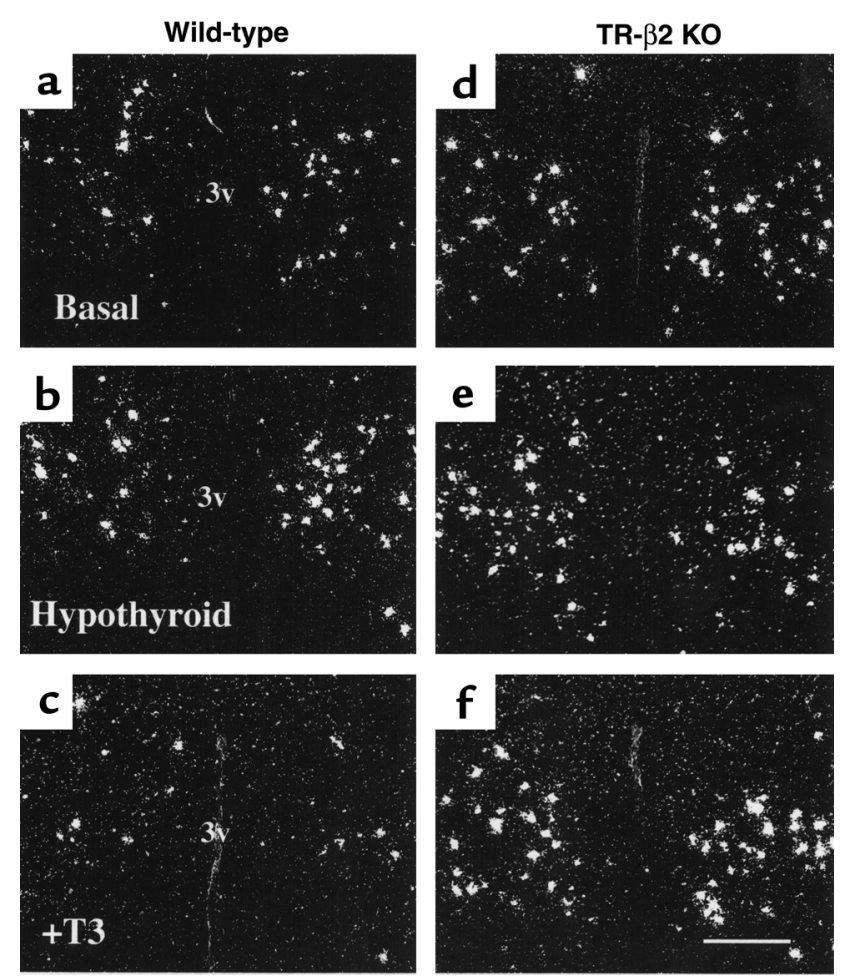
a

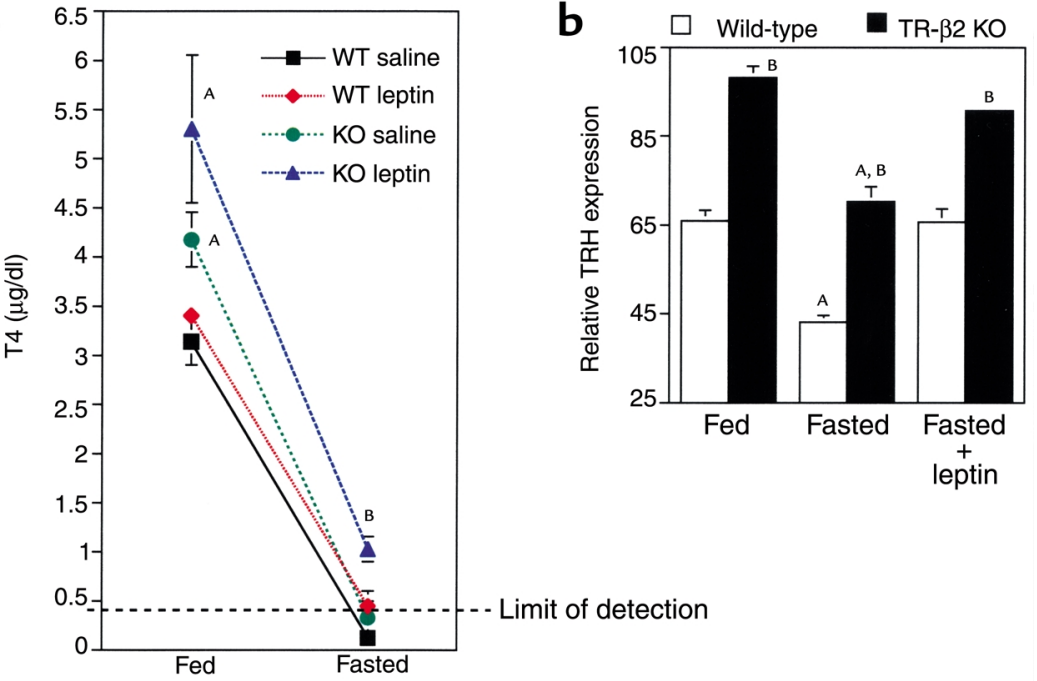

Figure 5

Thyroid hormone and TRH responses to fasting and leptin administration. (a) Fed and fasting $T_{4}$ concentrations in WT (black and red symbols) and TR- $\beta 2$-null (KO) mice (green and blue symbols). $n=4$ for all groups, except for saline-treated KO mice $(n=3)$. Data are mean \pm SEM. ${ }^{A} P<0.05$ versus fed $\mathrm{WT}$; ${ }^{\mathrm{B}} P<$ 0.05 versus all other fasted mice by ANOVA. (b) Relative prepro-TRH expression as assessed by laser densitometry in the rostral PVN of WT (open bars) and TR- $\beta 2 \mathrm{KO}$ mice (filled bars) at base line and after a 48- hour fast with and without leptin administration. Data shown are mean \pm SEM. Each point represents analysis of anatomically identical sections. $n=3 \mathrm{fed}$ groups, $n=3$ fasted $\mathrm{KO}, n=4$ all other groups. ${ }^{A} P<0.05$ versus fed or fasted plus leptin groups of same genotype, respectively. ${ }^{\mathrm{B}} P<0.05$ versus $\mathrm{WT}$ in the same treatment group by ANOVA. mone are required in order to increase $\mathrm{T}_{4}$ in RTH (18). The targeting of a mutant $\mathrm{TR}$ to the pituitary resulted in increased TSH production and TSH- $\beta$ gene expression. TRH expression was downregulated; $\mathrm{T}_{4}$ levels were normal and only increased after TRH administration. These observations imply that TRH plays an important role in modifying the bioactivity of TSH. Thus, increased basal TRH expression is likely to play an important role in mediating the increase in $\mathrm{T}_{4}$ concentrations observed in TR- $\beta 2$ knockout mice. TRH gene expression in TR- $\beta 2$ knockout mice at ambient levels of thyroid hormone were similar to those of hypothyroid mice. Yet basal TSH concentrations were significantly lower than levels obtained during hypothyroidism. This discrepancy between TRH and TSH production suggests that the binding of $\mathrm{T}_{3}$ to the remaining $\mathrm{TR}$ isoforms in the thyrotroph minimize any additional increase in TSH.

This conclusion is also supported by the differences in the responsiveness of the thyrotroph versus the TRH neurons to exogenous $T_{3}$ administration. $T_{3}$ administration to TR- $\beta 2$ knockout mice results in suppression of TSH- $\beta$ gene expression and $\mathrm{T}_{4}$ concentrations to $30 \%$ of basal levels (15). In contrast, TRH gene expression in the rostral and caudal PVN do not change. Thus, residual TR isoforms can mediate partial negative regulation in the thyrotroph, but fail to do so in the TRH neuron. Mice that lack all TR$\beta$ and TR- $\alpha$ isoforms develop massive elevations in $T_{4}$ and TSH concentrations, indicating that both iso-

\section{Figure 6}

Representative dark-field photomicrographs showing the response of prepro-TRH mRNA in the rostral PVN to the reduction in leptin levels during fasting in WT (a-c) and KO mice (d-f). TRH mRNA decreased with fasting and was restored by leptin. Scale bar, $300 \mu \mathrm{m}$. forms play an important role in regulating TSH production $(16,17)$. Analysis of the regulation of the TRH neuron in these mice has not been performed. However, pituitary selective expression of a mutant TR in TR- $\beta$-null mice recapitulates the hormonal abnormalities in the compound TR- $\alpha / \beta$ knockout mice (19). Taken together, these data, as well as our present findings, support the hypothesis that all TR isoforms are involved in the regulation of TSH- $\beta$ gene expression in the thyrotroph, whereas TR- $\beta 2$ is the important mediator in PVN TRH neurons.

In hypothyroid mice (wild-type and knockout), the increase in TSH concentrations and the degree of induc-
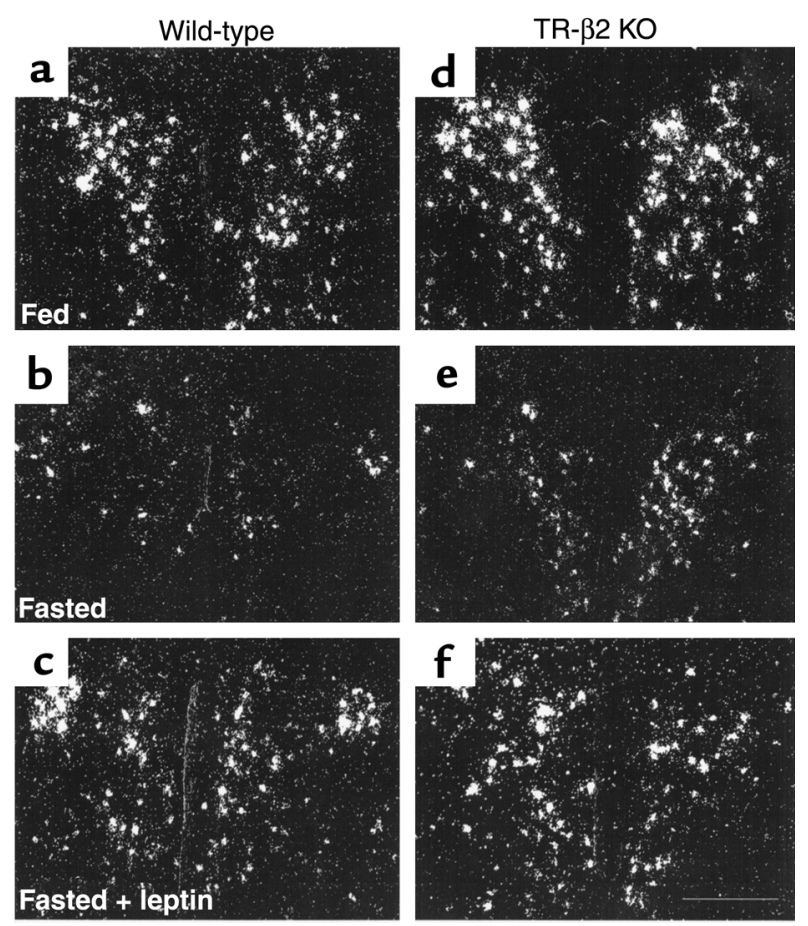
tion of TSH- $\beta$ gene expression were significantly greater than that observed for TRH. It is possible that this apparent discrepancy could result from limitations in our ability to quantify elevated TRH expression above certain levels by in situ hybridization histochemistry. However, these data raise additional possibilities regarding differences in the ligand-independent activation of the TSH subunit genes and the TRH gene in vivo. In wild-type mice hypothyroidism increased TSH expression more than 100-fold above base line whereas TRH expression was increased twofold to threefold, suggesting that TSH subunit genes (in vivo), are subject to greater ligand-independent activation in the absence of $\mathrm{T}_{3}$ than is the TRH gene. In TR- $\beta 2$-null mice, hypothyroidism increased TSH- $\beta$ expression by twofold to threefold, and TRH expression did not change. These observations suggest that residual TRs in the thyrotroph are able to mediate to a limited degree ligand-independent activation of the TSH- $\beta$ gene in the thyrotroph, but underscore the quantitatively important role of TR- $\beta 2$ in this process. In the $\mathrm{T}_{3}$-responsive neurons of the PVN, ligand-independent activation of TRH gene expression is completely absent in TR- $\beta 2$-null mice. This observation further supports our conclusion that TR- $\beta 2$ is the critical regulator of thyroid hormone action in the hypothalamus. The molecular mechanisms governing ligandindependent activation of these genes are partially understood, but are believed to involve the interaction of TRs with coactivator or corepressor molecules (23, 24). It will therefore be important in future studies to determine whether differences in the relative expression of known TR interacting proteins exist in the thyrotroph versus TRH neurons and to determine if such differences can account for the differences in ligand-independent activation of these genes in vivo.

Fasting leads to reduced activity of the HPT axis (25). The basis for this is decreased expression and synthesis of TRH (20). Recent data have revealed that a fall in leptin plays a central role in this phenomenon $(20,25)$ by its stimulatory effect on neurons in the arcuate nucleus, which project to the PVN (26), and by directly activating the TRH promoter by STAT3 phosphorylation (27). Leptin-mediated regulation of TRH gene expression is, in part, independent of the regulation of TRH expression by thyroid hormone. Thus we examined the regulation of TRH gene expression by leptin in TR$\beta 2$-null mice to determine if the defective $T_{3}$-mediated regulation was specific for TR-regulated pathways or was more generalized. TRH expression was modulated by fasting and leptin administration to equivalent degrees in wild-type and TR- $\beta 2$-null mice. However, at all points, null mice continued to exhibit greater TRH expression than wild-type controls. Thus responsiveness of TRH neurons to leptin is preserved in the absence of TR- $\beta 2$, whose major effect is in regulating the set point of TRH expression. These observations provide additional evidence for the multiple levels at which TRH expression is regulated in vivo, and strengthens our conclusions regarding the specific role of the TR- $\beta 2$ isoform in the regulation of TRH expression by thyroid hormone.

In conclusion, these studies define the essential and specific role of the TR- $\beta 2$ isoform in the regulation of TRH gene expression by thyroid hormone and define important differences between the thyrotroph and the TRH neurons in terms of TR isoform-mediated negative regulation.

\section{Acknowledgments}

We would like to thank Joseph Kelly, Charlotte Lee, and Dionne Rudder for technical assistance, and Anthony Hollenberg for helpful suggestions. The work was supported by the NIH grants DK-02485 to E.D. Abel and DK-49126 and DK-50564 to F.E. Wondisford. E.D. Abel was a recipient of a Faculty Development Award from the Robert Wood Johnson Foundation, the Eleanor and Miles Shore 50th Anniversary Scholars in Medicine Fellowship-Harvard Medical School, and a Thyroid Research Advisory Council Award.

1. Larsen, P.R. 1982. Thyroid-pituitary interaction: feedback regulation of thyrotropin secretion by thyroid hormones. N. Engl. J. Med. 306:23-32.

2. Yamada, M., et al. 1997. Tertiary hypothyroidism and hyperglycemia in mice with targeted disruption of the thyrotropin-releasing hormone gene. Proc. Natl. Acad. Sci. USA. 94:10862-10867.

3. Taylor, T., and Weintraub, B.D. 1989. Altered thyrotropin (TSH) carbohydrate structures in hypothalamic hypothyroidism created by paraventricular nuclear lesions are corrected by in vivo TSH-releasing hormone administration. Endocrinology. 125:2198-2203.

4. Chatterjee, V.K., Lee, J.K., Rentoumis, A., and Jameson, J.L. 1989. Negative regulation of the thyroid-stimulating hormone alpha gene by thyroid hormone: receptor interaction adjacent to the TATA box. Proc. Natl. Acad. Sci. USA. 86:9114-9118.

5. Wondisford, F.E., et al. 1989. Thyroid hormone inhibition of human thyrotropin beta-subunit gene expression is mediated by a cis-acting element located in the first exon. J. Biol. Chem. 264:14601-14604.

6. Hollenberg, A.N., et al. 1995. The human thyrotropin-releasing hormone gene is regulated by thyroid hormone through two distinct classes of negative thyroid hormone response elements. Mol. Endocrinol. 9:540-550.

7. Lazar, M.A. 1993.Thyroid hormone receptors: multiple forms, multiple possibilities. Endocr. Rev. 14:184-193.

8. Wood, W.M., Ocran, K.W., Gordon, D.F., and Ridgway, E.C. 1991. Isolation and characterization of mouse complementary DNAs encoding a and $b$ thyroid hormone receptors from thyrotrope cells: the mouse pituitary-specific b2 isoform differs at the amino terminus from the corresponding species from rat pituitary tumor cells. Mol. Endocrinol. 5:1049-1061.

9. Lechan, R.M., Yanping, Q., Jackson, I., and Mahdavi, V. 1994. Identification of thyroid hormone receptor isoforms in thyrotropin-releasing hormone neurons of the hypothalamic paraventricular nucleus. Endocrinology. 135:92-100.

10. Hodin, R.A., et al. 1989. Identification of a thyroid hormone receptor that is pituitary specific. Science. 244:76-79.

11. Fraichard, A., et al. 1997. The T3R alpha gene encoding a thyroid hormone receptor is essential for post-natal development and thyroid hormone production. EMBO J.16:4412-4420.

12. Wikstrom, L., et al. 1998. Abnormal heart rate and body temperature in mice lacking thyroid hormone receptor $\alpha 1$. EMBO J. 17:455-461.

13. Forrest, D., et al. 1996. Recessive resistance to thyroid hormone in mice lacking thyroid hormone receptor beta: evidence for tissue-specific modulation of receptor function. EMBOJ.15:3006-3015.

14. Weiss, R.E., et al. 1997. Thyrotropin regulation by thyroid hormone in thyroid hormone receptor $\beta$-deficient mice. Endocrinology. 138:3624-3629.

15. Abel, E.D., et al. 1999. Divergent roles for thyroid hormone receptor beta isoforms in the endocrine axis and auditory system. J. Clin. Invest. 104:291-300.

16. Gothe, S., et al. 1999. Mice devoid of all known thyroid hormone receptors are viable but exhibit disorders of the pituitary-thyroid axis, growth, and bone maturation. Genes Dev. 13:1329-1341.

17. Gauthier, K., et al. 1999. Different functions for the thyroid hormone receptors TRalpha and TRbeta in the control of thyroid hormone production and post-natal development. EMBOJ. 18:623-631.

18. Abel, E.D., et al. 1999. Novel insight from transgenic mice into thyroid hor- 
mone resistance and the regulation of thyrotropin. J. Clin. Invest. 103:271-279.

19. Abel, E.D., et al. 1998. Pituitary expression of a mutant thyroid hormone receptor in TR $\beta \mathrm{K} / \mathrm{O}$ mice results in marked elevations of thyroid hormone concentrations. Thyroid. 8(Suppl.):P110. (Abstr.)

20. Legradi, G., Emerson, C.H., Ahima, R.S., Flier, J.S., and Lechan, R.M. 1997. Leptin prevents fasting-induced suppression of prothyrotropinreleasing hormone messenger ribonucleic acid in neurons of the hypothalamic paraventricular nucleus. Endocrinology. 138:2569-2576.

21. Elmquist, J.K., Bjorbaek, C., Ahima, R.S., Flier, J.S., and Saper, C.B. 1998 Distribution of leptin receptor mRNA isoforms in the rat brain. J. Comp. Neurol. 395:535-547.

22. Franklin, K.B., and Paxinos, G. 1997. The mouse brain in stereotaxic coordinates. Academic Press. New York, New York, USA. 210 pP.

23. Oberste-Berghaus, C., et al. 2000. Thyroid hormone-independent inter- action between the thyroid hormone receptor beta2 amino terminus and coactivators. J. Biol. Chem. 275:1787-1792.

24. Tagami, T., Madison, L.D., Nagaya, T., and Jameson, J.L. 1997. Nuclear receptor corepressors activate rather than suppress basal transcription of genes that are negatively regulated by thyroid hormone. Mol. Cell. Biol. 17:2642-2648.

25. Ahima, R.S., et al. 1996. Role of leptin in the neuroendocrine response to fasting. Nature. 382:250-252.

26. Legradi, G., et al. 1998. Arcuate nucleus ablation prevents fastinginduced suppression of ProTRH mRNA in the hypothalamic paraventricular nucleus. Neuroendocrinology. 68:89-97.

27. Harris, M., et al. 2001. Transcriptional regulation of the thyrotropinreleasing hormone gene by leptin and melanocortin signaling. J. Clin. Invest.107:111-120. 